\author{
S.K. Tleukenov, K.N. Balabekov, Z.K. Zhalgasbekova \\ L.N. Gumilyov Eurasian National University, Nur-Sultan, Kazakhstan \\ (E-mail:matricant@inbox.ru)
}

\title{
Laws of reflection and refraction of TE and TM polarization waves on the border of rhombic crystals
}

\begin{abstract}
The article analytically solves the problem of reflection and refraction of electromagnetic plane waves of different polarization at the boundary of anisotropic half-spaces of rhombic symmetry. Based on the matrix method, the angles of refraction of electromagnetic waves of different polarization, the amplitudes of the reflected and refracted waves, the angles that determine the direction of the group velocities and vectors of the flow of electromagnetic energy, the magnitudes of the flows of electromagnetic energy and their components depending on the direction of the wave vector of the incident wave are determined. The determination of the angles of total internal reflection and the refractive index of electromagnetic waves of different polarization is considered. A significantly different dependence of the kinematic and energy characteristics of electromagnetic waves of different polarization on the anisotropy of the magnetic and dielectric tensors is shown. For electromagnetic waves, the polarization of which is determined by the component of the electric tension vector perpendicular to the wave propagation plane (TE wave), the characteristics of the reflected and refracted waves, the velocity indicatrix, the propagation angles, etc. determined primarily by the components of the magnetic permeability tensor. In the case of electromagnetic waves, when the polarization is determined by the component of the magnetic field (TM wave), perpendicular to the plane of wave propagation, all characteristics depend mainly on the components of the dielectric constant. The validity of the Fresnel formulas for determining the coefficients of reflected and refracted waves at the boundary of anisotropic media of rhombic symmetry is shown. However, in this case, the components of the wave vectors included in the Fresnel formulas are determined by their indicatrices. In addition, it is necessary to take into account the dependence of these components on the angle of refraction in the second medium.
\end{abstract}

Key words: anisotropy, rhombic symmetry, electromagnetic waves, reflection, refraction, wave refraction angles, phase and group velocities, density vector.

\section{Introduction}

Wave processes in anisotropic media are qualitatively different from the patterns of wave propagation in isotropic media.

The magnitude of the phase velocity of the waves in an anisotropic medium depends on the direction of propagation. The transfer of electromagnetic energy is determined by the group velocity of the wave. The directions of the vectors of phase and group velocities and their values do not coincide [1-3].

The influence of the anisotropy of dielectric media on electromagnetic wave processes is described by the anisotropy of the dielectric and magnetic tensors.

Traditionally, in connection with the study of the optical range and optically transparent media, the physical processes of propagation, scattering of electromagnetic waves in anisotropic media are considered, considering the magnetic permeability equal to unity. Only the anisotropy of the dielectric constant tensor is taken into account [1-5]

Theoretical and experimental work is currently being intensively carried out related to piezomagnetic, magnetostrictive, and magnetoelectric effects and their practical application. The widespread use and importance of materials with piezoelectric effects for acoustoelectronics is well known [6-11].

Moreover, the study of the laws of electromagnetic wave processes taking into account the anisotropy of the dielectric and magnetic permeability tensors shows their significantly different influence on the propagation of TE and TM polarization waves [12-14].

Anisotropy of crystals, the manifestation of the anisotropic properties of media under various physical and mechanical conditions, the creation of artificial materials necessitates a detailed study of the laws of electromagnetic wave processes in media of different symmetries, taking into account the anisotropy of the dielectric and magnetic permeability parameters.

The aim of the work is to construct an analytical solution to the problems of reflection, refraction of TE and TM polarized waves at the boundary of anisotropic half-spaces of rhombic symmetry, determination of 
the angle of refraction of waves, directions of group velocities, amplitudes of reflected and refracted waves, calculation of the components of the vectors of electromagnetic energy flux and group velocity depending on the direction wave vector of the incident wave.

\section{Matrix equation}

The Maxwell initial equations

$$
\begin{gathered}
\operatorname{rot} \vec{E}=-\frac{\partial \vec{B}}{\partial t} ; \\
\operatorname{rot} \vec{H}=\frac{\partial \vec{D}}{\partial t} ; \\
\operatorname{div} \vec{D}=0 ; \operatorname{div} \vec{B}=0 ; \vec{j}=0, \rho=0 ; \\
D_{i}=\varepsilon_{i j} E_{J} ; B_{i}=\mu_{i j} H_{j}
\end{gathered}
$$

and tensors of dielectric and magnetic permeability of rhombic anisotropy:

$$
\hat{\varepsilon}=\left(\begin{array}{ccc}
\varepsilon_{x} & 0 & 0 \\
0 & \varepsilon_{y} & 0 \\
0 & 0 & \varepsilon_{z}
\end{array}\right) ; \hat{\mu}=\left(\begin{array}{ccc}
\mu_{x} & 0 & 0 \\
0 & \mu_{y} & 0 \\
0 & 0 & \mu_{z}
\end{array}\right) .
$$

Absolute permeability of $\varepsilon_{0}, \mu_{0}$ contained (included) $\varepsilon_{i j}, \mu_{i j}$.

Based on the presentation of decisions:

$$
f(x, y, z, t)=\bar{f}(z) e^{i \omega t-i k_{x} x-i k_{y} y}
$$

the system of equations (1) is reduced to the matrix equation [12-18]

$$
\frac{d \vec{W}}{d t}=B \vec{W} ; \vec{W}=\left(\mathrm{E}_{y}, \mathrm{H}_{x}, \mathrm{H}_{y}, \mathrm{E}_{x}\right)^{t}
$$

is the transpose sign of the row vector into the column vector.

The matrix of coefficients $B$ has the structure:

with elements $b_{i j}$ :

$$
B=\left(\begin{array}{cccc}
0 & b_{12} & b_{13} & 0 \\
b_{21} & 0 & 0 & b_{24} \\
-b_{24} & 0 & 0 & b_{34} \\
0 & -b_{13} & b_{43} & 0
\end{array}\right)
$$

$$
\begin{gathered}
b_{12}=i \omega \mu_{x}-i \frac{k_{y}^{2}}{\omega \varepsilon_{z}}, b_{13}=i \frac{k_{x} k_{y}}{\omega \varepsilon_{z}} ; \\
b_{21}=i \omega \varepsilon_{y}-i \frac{k_{x}^{2}}{\omega \mu_{z}}, b_{24}=i \frac{k_{x} k_{y}}{\omega \mu_{z}} ; \\
b_{34}=-i \omega \varepsilon_{x}+i \frac{k_{y}^{2}}{\omega \mu_{z}}, b_{42}=-i \omega \mu_{y}+i \frac{k_{x}^{2}}{\omega \varepsilon_{z}} .
\end{gathered}
$$

In the framework of the matrix method in the case of homogeneous media, the equations of the surface of wave vectors can be determined from the condition $[12-14,16]$.

Here $I$ is the identity matrix.

$$
\operatorname{det}\left[B^{2}+k_{z}^{2} I\right]=0 \text {. }
$$

2. Waves of TE polarization.

2.1 For waves of TE polarization in the coordinate plane, matrix equation follows from (4-6)

$$
\begin{gathered}
\frac{d \vec{W}}{d z}=B \vec{W} ; \\
B=\left(\begin{array}{cc}
0 & b_{12} \\
b_{21} & 0
\end{array}\right) ;
\end{gathered}
$$




$$
\begin{gathered}
\vec{W}=\left(\mathrm{E}_{y}, \mathrm{H}_{x}\right)^{t} ; \\
b_{12}=i w \mu_{x} ; \\
b_{21}=i w\left(\varepsilon_{y}-\frac{k_{x}^{2}}{w^{2} \mu_{z}}\right) .
\end{gathered}
$$

Equation (7) has an analytical solution. In the form of a matrix, it has the form of:

$$
T=I \cos k_{z} z+\frac{B}{k_{z}} \sin k_{z} z ; \quad I=\left(\begin{array}{cc}
1 & 0 \\
0 & 1
\end{array}\right) .
$$

To solve the problems of reflection refraction, it is converted to the form:

$$
T=\frac{1}{2}\left(I+\frac{B}{i k_{z}} e^{i k_{0} z}\right)+\frac{1}{2}\left(I-\frac{B}{i k_{z}}\right) e^{-i k_{z} z} .
$$

The first term describes the backward waves, the second: the direct waves in (8) and (9) omit the factor $e^{i w t}$.

The condition of continuity of the incident wave fields $\left(\vec{W}_{0}\right)$, reflected $\left(\vec{W}_{R}\right)$ and refracted $W_{T}$ waves at the interface of $(z=0)$, based (9) has the form of:

$$
\left(\frac{1}{2} I-R_{0}\right) \vec{W}_{0}+\left(\frac{1}{2} I+R_{0}\right) \vec{W}_{R}=\left(\frac{1}{2} I-R\right) \vec{W}_{T} ;
$$

Given the continuity of decisions:

$$
\vec{W}_{0}+\vec{W}_{R}=\vec{W}_{T} \text { at } z=0
$$

from (10) it can be taken:

$$
\left(R_{0}+R\right) \vec{W}_{R}=\left(R_{0}-R\right) \vec{W}_{0} .
$$

Boundary Matrixes of $R_{0}$ and $R$ have the form of:

$$
R_{0}=\frac{1}{2 i k_{0 z}} B_{0} ; \quad R=\frac{1}{2 i k_{z}} B .
$$

The field of reflected waves is determined based on (12):

$$
\vec{W}_{R}=\left(R_{0}+R\right)^{-1}\left(R_{0}-R\right) \vec{W}_{0} ;
$$

field of refracted waves $\vec{W}_{T}$ follows from (11)

By introducing the following notation:

$$
\vec{W}_{T}=\left[I+\left(R_{0}+R\right)^{-1}\left(R_{0}-R\right)\right] \vec{W}_{0} .
$$

$$
\begin{gathered}
\left(R_{0} \pm R\right)=\frac{1}{2 i}\left(\begin{array}{cc}
0 & r_{12}^{ \pm} \\
r_{21}^{ \pm} & 0
\end{array}\right) ; \\
r_{12}^{ \pm}=\frac{b_{12}^{0}}{k_{0 z}} \pm \frac{b_{12}}{k_{z}} ; r_{21}^{ \pm}=\frac{b_{21}^{0}}{k_{0 z}} \pm \frac{b_{21}}{k_{z}}
\end{gathered}
$$

after calculations:

$$
\left(R_{0}+R\right)^{-1}\left(R_{0}-R\right)=\left(\begin{array}{cc}
\frac{r_{21}^{-}}{r_{21}^{+}} & 0 \\
0 & \frac{r_{12}^{-}}{r_{12}^{+}}
\end{array}\right) .
$$

2.2 Amplitudes of reflected and refracted waves of TE polarization.

From (17) it follows:

$$
\frac{r_{21}^{-}}{r_{21}^{+}}=\frac{b_{21}^{0} k_{z}-b_{21} k_{0 z}}{b_{21}^{0} k_{z}+b_{21} k_{0 z}}=\frac{\mu_{x} k_{0 z}-k_{z} \mu_{x 0}}{\mu_{x} k_{0 z}+k_{z} \mu_{x 0}},
$$

it is taken into account that:

$$
b_{12} b_{21}+k_{z}^{2}=0 \text {. }
$$

It is followed from (17). 
Similarly:

$$
\frac{r_{12}^{-}}{r_{12}^{+}}=\frac{b_{12}^{0} k_{z}-k_{0 z} b_{12}}{b_{12}^{0} k_{z}+k_{0 z} b_{12}}=\frac{\mu_{x 0} k_{z}-\mu_{x} k_{0 z}}{\mu_{x 0} k_{z}+\mu_{x} k_{0 z}} .
$$

Amplitudes of reflected waves:

$$
\begin{gathered}
E_{y R}=\frac{r_{21}^{-}}{r_{21}^{+}} E_{y 0} ; \frac{H_{x R}}{H_{x 0}}=-\frac{E_{y R}}{E_{y 0}} ; \\
H_{x 0}=-\frac{k_{0 z}}{\omega \mu_{x 0}} E_{y 0} ; H_{x R}=\frac{k_{z 0}}{\omega \mu_{x 0}} E_{y R} ; \\
H_{z 0}=\frac{k_{x 0}}{\omega \mu_{z 0}} E_{y 0} ; H_{z R}=\frac{k_{z 0}}{\omega \mu_{x 0}} E_{y R} .
\end{gathered}
$$

For a refracted wave:

$$
\begin{gathered}
E_{y T}=E_{y 0}+E_{y R}=\frac{2 \mu_{x} k_{0 z}}{\mu_{x} k_{0 z}+\mu_{x 0} k_{z}} E_{y 0} ; \\
H_{x T}=-\frac{k_{z}}{w \mu_{x}} E_{y T} ; H_{z}=\frac{k_{x}}{w \mu_{z}} E_{y T} .
\end{gathered}
$$

2.3 The angle of refraction of the TE wave. Components of wave vectors.

Formulas (18)-(23) have the form of Fresnel formulas [1-3]. The difference lies in obtaining values $k_{0 z}, k_{z}, k_{x}, k_{x 0}$ based on indicatrixes of wave vectors in an anisotropic medium [12-14].

From (19) follows the equation of the indicatrix $k$

$$
k^{2}=\frac{\omega^{2} \varepsilon_{y} \mu_{x} \mu_{z}}{\mu_{z} \cos ^{2} \theta+\mu_{x} \sin ^{2} \theta} .
$$

At the media boundary, the following conditions must be met:

$$
k_{0 x}=k_{x} \Rightarrow k_{0} \sin \theta_{0}=k \sin \theta,
$$

$\theta_{0}$ - determines the direction of the $\vec{k}_{0}$ incident wave vector; $\theta$ - wave refraction angle $(\vec{k})$.

Condition (25) based on (24) gives:

From (26) follows:

$$
\frac{\varepsilon_{y 0} \mu_{x 0} \mu_{z 0} \sin ^{2} \theta_{0}}{\mu_{z 0} \cos ^{2} \theta_{0}+\mu_{x 0} \sin ^{2} \theta_{0}}=\frac{\varepsilon_{y} \mu_{x} \mu_{z} \sin ^{2} \theta}{\mu_{z} \cos ^{2} \theta+\mu_{x} \sin ^{2} \theta} .
$$

$$
\sin ^{2} \theta=\frac{\varepsilon_{y 0} \mu_{x 0} \mu_{z 0} \mu_{z} \sin ^{2} \theta_{0}}{\varepsilon_{y} \mu_{x} \mu_{z} \mu_{z 0}-\left[\varepsilon_{y} \mu_{x} \mu_{z}\left(\mu_{x 0}-\mu_{z 0}\right)+\varepsilon_{y 0} \mu_{x 0} \mu_{z 0}\left(\mu_{x}-\mu_{z}\right)\right] \sin ^{2} \theta_{0}} .
$$

Formula (27) determines the angle $\theta$ of the refracted wave $\theta_{0}$ as a function of rhombic symmetry at the crystal boundary. If the first medium is isotropic, then: $\left(\mu_{x 0}=\mu_{z 0}\right)$.

$$
\sin ^{2} \theta=\frac{\mu_{z} \varepsilon_{y 0} \mu_{x 0} \sin ^{2} \theta_{0}}{\mu_{z} \mu_{x} \varepsilon_{y}-\varepsilon_{y 0} \mu_{x 0}\left(\mu_{x}-\mu_{z}\right) \sin ^{2} \theta_{0}}
$$

With the isotropy of both media:

$$
\sin ^{2} \theta=\frac{\varepsilon_{y 0} \mu_{x 0}}{\mu_{x} \varepsilon_{y}} \sin ^{2} \theta_{0}
$$

The angle of total internal reflection can be determined by setting either

$$
\sin ^{2} \theta=1 \text {, or } \sin ^{2} \theta_{0}=1 \text {. }
$$

If it is $\sin ^{2} \theta=1$, then the full reflection of the wave propagating in the first medium will be subject to:

$$
\sin ^{2} \theta_{0}=\frac{\varepsilon_{y} \mu_{z} \mu_{z 0}}{\varepsilon_{y 0} \mu_{x 0} \mu_{z 0}+\varepsilon_{y} \mu_{z}\left(\mu_{x 0}-\mu_{z 0}\right)} .
$$

The quantities $k_{0 z}$ and $k_{z}$ included in the reflection and refraction formulas (18)-(23) are determined on the basis of (24): 


$$
\begin{gathered}
k_{0 z}^{2}=\frac{\omega^{2} \varepsilon_{y 0} \mu_{x 0} \mu_{z 0} \cos ^{2} \theta_{0}}{\mu_{z 0} \cos ^{2} \theta_{0}+\mu_{x 0} \sin ^{2} \theta_{0}}=k_{0}^{2} \cos ^{2} \theta_{0} ; \\
k_{z}^{2}=\frac{\omega^{2} \varepsilon_{y} \mu_{x} \mu_{z} \cos ^{2} \theta}{\mu_{z} \cos ^{2} \theta+\mu_{x} \sin ^{2} \theta}=k^{2} \cos ^{2} \theta .
\end{gathered}
$$

In (32), it must be borne in mind that the angle $\theta$ is determined by expressions (26), (27).

2.4 Energy ratios.

When TE waves propagate in the $x o z$ plane the electromagnetic field in the medium has non-zero components:

$$
E_{y}, H_{x}, H_{z} \text {. }
$$

The difference from zero $H_{z}$ is a consequence of electromagnetic induction and is determined from the equation:

$$
\operatorname{rot} \vec{E}=-\frac{\partial \vec{B}}{\partial t}
$$

Components $H_{x}$ and $H_{z}$ related $E_{y}$ ratios:

$$
H_{x}=-\frac{k_{z}}{w \mu_{x}} E_{y}, H_{z}=-\frac{k_{x}}{w \mu_{z}} E_{y} .
$$

The electromagnetic energy flux vector has components:

$$
\vec{S}=[\vec{E} \times \vec{H}]=\vec{i} S_{x}+\vec{k} S_{z}=\vec{i} E_{y} H_{z}-\vec{k} E_{y} H_{x},
$$

with (35), it must be taken:

$$
S_{x}=\frac{k_{x}}{\omega \mu_{z} \varepsilon_{y}} \varepsilon_{y} E_{y}^{2} ; S_{z}=\frac{k_{z}}{\omega \mu_{x} \varepsilon_{y}} \varepsilon_{y} E_{y}^{2} .
$$

The components $S_{x}, S_{z}$ for the incident, reflected and refracted waves are:

$$
\begin{aligned}
& S_{z 0}=\frac{k_{z 0}}{\omega \mu_{x 0}} E_{y 0}^{2} ; S_{x 0}=\frac{k_{x 0}}{\omega \mu_{z 0}} E_{y 0}^{2} ; \\
& S_{z R}=\frac{k_{z 0}}{\omega \mu_{x 0}} E_{y R}^{2} ; S_{x R}=\frac{k_{x 0}}{\omega \mu_{z 0}} E_{y R}^{2} ; \\
& S_{z T}=\frac{k_{z}}{\omega \mu_{x}} E_{y T}^{2} ; S_{x T}=\frac{k_{x}}{\omega \mu_{z}} E_{y T}^{2} .
\end{aligned}
$$

The direction of the vector $\vec{S}$ coinciding with the direction of the group velocity [4, 5] is determined by the ratio:

$$
\frac{S_{x}}{S_{z}}=\operatorname{tg} \beta=\frac{\mu_{x}}{\mu_{z}} \operatorname{tg} \theta
$$

Angle $\theta$ determines the direction of the wave vector $\vec{k}$, angle $\beta$ the direction of the group velocity vector.

The full stream is:

$$
S=\sqrt{S_{x}^{2}+S_{z}^{2}}=V_{g} \varepsilon_{y} E_{y}^{2}
$$

Here is the group velocity $V_{g}$ :

$$
V_{g}^{2}=\left(\frac{k_{x}}{\omega \mu_{z} \varepsilon_{y}}\right)^{2}+\left(\frac{k_{z}}{\omega \mu_{x} \varepsilon_{y}}\right)^{2}=\frac{1}{\varepsilon_{y} \mu_{x} \mu_{z}} \frac{\mu_{z}^{2}+\mu_{x}^{2} \operatorname{tg}^{2} \theta}{\mu_{z}+\mu_{x} t^{2} \theta} .
$$

The phase velocity of the TE polarization wave is determined from (24)

$$
V_{f}^{2}=\frac{1}{\varepsilon_{y} \mu_{x} \mu_{z}}\left(\mu_{z} \cos ^{2} \theta+\mu_{x} \sin ^{2} \theta\right) .
$$


For the refractive index:

$$
n^{2}=\frac{c^{2}}{V_{f}^{2}}=\frac{c^{2} \varepsilon_{y} \mu_{x} \mu_{z}}{\mu_{z} \cos ^{2} \theta+\mu_{x} \sin ^{2} \theta},
$$

$c$ - speed of electromagnetic waves in vacuum.

In an anisotropic medium $n=n(\theta)$.

From (37)-(39) it follows that for $S_{z R}, S_{z 0}, S_{z T}$, the relation:

$$
\frac{S_{z R}}{S_{z 0}}+\frac{S_{z T}}{S_{z 0}}=1
$$

Insofar as:

$$
\begin{gathered}
\frac{S_{z R}}{S_{z 0}}=\frac{E_{y R}^{2}}{E_{y 0}^{2}}=\left(\frac{\mu_{x} k_{0 z}-k_{z} \mu_{x 0}}{\mu_{x} k_{0 z}+k_{z} \mu_{x 0}}\right)^{2} ; \\
\frac{S_{z T}}{S_{z 0}}=\frac{k_{z} \mu_{x 0}}{\mu_{x} k_{z 0}}\left(\frac{2 \mu_{x} k_{0 z}}{\mu_{x} k_{0 z}+k_{z} \mu_{x 0}}\right)^{2} .
\end{gathered}
$$

The sum of the right-hand sides of equalities $(46),(47)$ is equal to one.

Thus: formulas (18)-(23), (31), (32) determine the amplitudes of the reflected and refracted waves; based on (24)-(27), the angles of refraction are determined at the boundary of anisotropic media; formulas (36)-(39) determine the flows of electromagnetic energy; (42), (43) give the values of the group and phase velocities; (40) determines the direction of the group velocity vector and the flow of electromagnetic energy (41).

\section{Waves of TM polarization}

The propagation of TM polarized waves in the plane, as follows (4)-(6), $k_{y}=0$ is described by the matrix equation:

$$
\begin{gathered}
\frac{d}{d z} \vec{W}=B \vec{W} ; \vec{W}=\left(H_{y}, E_{x}\right)^{t} ; \\
B=\left(\begin{array}{cc}
0 & b_{12} \\
b_{21} & 0
\end{array}\right) ; \\
b_{12}=-i w \varepsilon_{x} ; \\
b_{21}=-i w\left(\mu_{y}-\frac{k_{x}^{2}}{w^{2} \varepsilon_{z}}\right) .
\end{gathered}
$$

3.1 The amplitudes of the reflected and refracted waves of the TM polarization are determined by the expressions (18)-(20), with $b_{i j}$; from (48):

From (14) and (17) follows:

$$
\begin{gathered}
\frac{r_{21}^{-}}{r_{21}^{+}}=\frac{\varepsilon_{x} k_{0 z}-\varepsilon_{x 0} k_{z}}{\varepsilon_{x} k_{0 z}+\varepsilon_{x 0} k_{z}} ; \\
\frac{r_{12}^{-}}{r_{12}^{+}}=-\frac{r_{21}^{-}}{r_{21}^{+}} .
\end{gathered}
$$

$$
H_{y R}=\frac{r_{21}^{-}}{r_{21}^{+}} H_{y 0} ; \frac{H_{y T}}{H_{y 0}}=\frac{2 \varepsilon_{x} k_{0 z}}{\varepsilon_{x} k_{0 z}+k_{z} \varepsilon_{x 0}} .
$$

The electromagnetic field of a TM polarized wave in a medium has non-zero components:

$$
H_{y}, E_{x}, E_{z} \text {. }
$$

The components $E_{x}$ and $E_{z}$ and $H_{y}$ are related by the relations:

$$
E_{x}=\frac{k_{z}}{\omega \varepsilon_{x}} H_{y} ; E_{z}=-\frac{k_{x}}{\omega \varepsilon_{z}} H_{y} .
$$




$$
E_{x 0}=\frac{k_{z 0}}{\omega \varepsilon_{x 0}} H_{y 0} ; E_{x R}=-\frac{k_{z 0}}{\omega \varepsilon_{z 0}} H_{y R} .
$$

3.2 The angle of refraction of the TM wave. Components of wave vectors.

The indicatrix of the wave vector of the TM wave is determined by condition (7), taking into account with $b_{i j}$ (48)

$$
k^{2}=\frac{\omega^{2} \mu_{y} \varepsilon_{x} \varepsilon_{z}}{\varepsilon_{z} \cos ^{2} \theta+\varepsilon_{x} \sin ^{2} \theta} .
$$

From equality: $k_{x 0}=k_{x}$ at the media boundary, the law of refraction of TM polarization waves follows

$$
\frac{\mu_{y 0} \varepsilon_{x 0} \varepsilon_{z 0} \sin ^{2} \theta_{0}}{\varepsilon_{z 0} \cos ^{2} \theta_{0}+\varepsilon_{x} \sin ^{2} \theta_{0}}=\frac{\mu_{y} \varepsilon_{x} \varepsilon_{z} \sin ^{2} \theta}{\varepsilon_{z} \cos ^{2} \theta+\varepsilon_{x} \sin ^{2} \theta} .
$$

From (55) it can be taken:

$$
\sin ^{2} \theta=\frac{\mu_{y 0} \varepsilon_{x 0} \varepsilon_{z 0} \varepsilon_{z} \sin ^{2} \theta_{0}}{\mu_{y} \varepsilon_{x} \varepsilon_{z} \varepsilon_{z 0}-\left[\mu_{y} \varepsilon_{x} \varepsilon_{z}\left(\varepsilon_{x 0}-\varepsilon_{z 0}\right)+\mu_{y 0} \varepsilon_{x 0} \varepsilon_{z 0}\left(\varepsilon_{x}-\varepsilon_{z}\right)\right] \sin ^{2} \theta_{0}} .
$$

The angle $\theta_{0}$ determines the direction of the vector $\vec{k}_{0}$ of the wave incident on the boundary of the TM wave $\theta$; the angle determines the direction of the vector $\vec{k}$ of the refracted wave. Similarly to formulas (28), (29), special cases can be obtained.

The angles of total internal reflection can also be obtained on the basis of (56) by setting either $\sin ^{2} \theta_{0}=1$, or $\sin ^{2} \theta=0$.

When $\sin ^{2} \theta=1$ has

$$
\sin ^{2} \theta_{0}=\frac{\mu_{y} \varepsilon_{z} \varepsilon_{z 0}}{\mu_{y 0} \varepsilon_{z 0} \varepsilon_{x 0}+\mu_{y} \varepsilon_{z}\left(\varepsilon_{x 0}-\varepsilon_{z 0}\right)} .
$$

The components of the wave vectors $k_{0 z}$ and $k_{z}$ included in the refraction reflection formulas (49)-(51) are determined based on the indicatrix equation for both media (54)

$$
\begin{gathered}
k_{0 z}^{2}=\frac{\omega^{2} \mu_{y 0} \varepsilon_{x 0} \varepsilon_{z 0}}{\varepsilon_{z 0} \cos ^{2} \theta_{0}+\varepsilon_{x 0} \sin ^{2} \theta_{0}} ; \\
k_{z}^{2}=\frac{\omega^{2} \mu_{y} \varepsilon_{x} \varepsilon_{z}}{\varepsilon_{z} \cos ^{2} \theta+\varepsilon_{x} \sin ^{2} \theta} .
\end{gathered}
$$

As in the case of TE waves of polarization (32), the angle $\theta$ is determined by relations (55), (56) (in the case of TE waves (26), (27).

Energy relations for TM polarized waves.

The vector of electromagnetic energy flow $\vec{S}$ has the form:

$$
\begin{gathered}
\vec{S}=[\vec{E} \times \vec{H}]=i S_{x}+k S_{z}=-\vec{i} H_{y} E_{z}+\vec{k} H_{y} E_{x} . \\
S_{x}=\frac{k_{x}}{\omega \varepsilon_{z}} H_{y}^{2} ; S_{z}=\frac{k_{z}}{\omega \varepsilon_{x}} H_{y}^{2} .
\end{gathered}
$$

In (61), dependences (53) were taken into account

The direction of the group velocity vector and the electromagnetic energy flux vector is determined by the formula.

$$
\frac{S_{x}}{S_{z}}=\operatorname{tg} \beta=\frac{\varepsilon_{x}}{\varepsilon_{z}} \operatorname{tg} \theta
$$

The angle $\beta$ determines the direction of the group velocity vector $\vec{V}_{g}$.

The components of the electromagnetic energy flows for a TM wave have the following meanings.

- incident wave

$$
S_{x 0}=\frac{k_{x 0}}{\omega \varepsilon_{z 0}} H_{y 0}^{2} ; S_{z 0}=\frac{k_{z 0}}{\omega \varepsilon_{x 0}} H_{y 0}^{2}
$$


- reflected wave

- refracted wave

$$
S_{x R}=\frac{k_{x 0}}{\omega \varepsilon_{z 0}} H_{y R}^{2} ; S_{z R}=\frac{k_{z 0}}{\omega \varepsilon_{x 0}} H_{y R}^{2}
$$

$$
S_{x T}=\frac{k_{x}}{\omega \varepsilon_{z}} H_{y T}^{2} ; S_{z T}=\frac{k_{z}}{\omega \varepsilon_{x}} H_{y T}^{2} .
$$

The quantities $H_{y R}, H_{y T}$ are determined by relations (49)-(51), and are related by relationships (53).

Calculation of the total flow gives:

$$
S=\sqrt{S_{x}^{2}+S_{z}^{2}}=V_{g} \mu_{y} H_{y}^{2} .
$$

The value of the group velocity $V_{g}$ is equal to:

$$
V_{g}^{2}=\frac{1}{\mu_{y} \varepsilon_{x} \varepsilon_{z}} \frac{\varepsilon_{z}^{2}+\varepsilon_{x}^{2} \operatorname{tg}^{2} \theta}{\varepsilon_{z}+\varepsilon_{x} \operatorname{tg}^{2} \theta} .
$$

Phase speed:

$$
V_{f}^{2}=\frac{\varepsilon_{z} \cos ^{2} \theta+\varepsilon_{x} \sin ^{2} \theta}{\mu_{y} \varepsilon_{x} \varepsilon_{z}}=\frac{\omega^{2}}{k^{2}} .
$$

Refractive index:

$$
n^{2}=\frac{c^{2}}{V_{f}^{2}}=\frac{c^{2} \mu_{y} \varepsilon_{x} \varepsilon_{z}}{\varepsilon_{z} \cos ^{2} \theta+\varepsilon_{x} \sin ^{2} \theta},
$$

$c$ - speed of electromagnetic waves in vacuum.

For the components of the flows $S_{z 0}, S_{z R}, S_{z T}$, the equality is:

$$
\frac{S_{z R}}{S_{z 0}}+\frac{S_{z T}}{S_{z 0}}=1
$$

The proof is similar. (46), (47).

\section{Settlement part}

1. Indicatrixes of wave vectors of TE and TM polarization waves in an anisotropic medium of rhombic symmetry:

$$
\begin{aligned}
& k_{T E}^{2}=\frac{\omega^{2} \varepsilon_{y} \mu_{x} \mu_{z}}{\mu_{z} \cos ^{2} \theta+\mu_{x} \sin ^{2} \theta} ; \\
& k_{T M}^{2}=\frac{\omega^{2} \mu_{y} \varepsilon_{x} \varepsilon_{z}}{\varepsilon_{z} \cos ^{2} \theta+\varepsilon_{x} \sin ^{2} \theta} .
\end{aligned}
$$

2. Phase velocities:

$$
\begin{aligned}
& V_{f T E}^{2}=\frac{1}{\varepsilon_{y} \mu_{x} \mu_{z}}\left(\mu_{z} \cos ^{2} \theta+\mu_{x} \sin ^{2} \theta\right) ; \\
& V_{f T M}^{2}=\frac{1}{\mu_{y} \varepsilon_{x} \varepsilon_{z}}\left(\varepsilon_{z} \cos ^{2} \theta+\varepsilon_{x} \sin ^{2} \theta\right) .
\end{aligned}
$$

3. Group speeds:

$$
\begin{aligned}
& V_{g T E}^{2}=\frac{1}{\varepsilon_{y} \mu_{x} \mu_{z}} \frac{\mu_{z}^{2}+\mu_{x}^{2} \operatorname{tg}^{2} \theta}{\mu_{z}+\mu_{x} \operatorname{tg}^{2} \theta} ; \\
& V_{g T M}^{2}=\frac{1}{\mu_{y} \varepsilon_{x} \varepsilon_{z}} \frac{\varepsilon_{z}^{2}+\varepsilon_{x}^{2} \operatorname{tg}^{2} \theta}{\varepsilon_{z}+\varepsilon_{x} \operatorname{tg}^{2} \theta} .
\end{aligned}
$$


4. The refraction angles of TE and TM waves at the boundary of rhombic symmetry media:

- for TE polarization waves:

$$
\sin ^{2} \theta=\frac{\varepsilon_{y 0} \mu_{x 0} \mu_{z 0} \mu_{z} \sin ^{2} \theta_{0}}{\varepsilon_{y} \mu_{x} \mu_{z} \mu_{z 0}-\left[\varepsilon_{y} \mu_{x} \mu_{z}\left(\mu_{x 0}-\mu_{z 0}\right)+\varepsilon_{y 0} \mu_{x 0} \mu_{z 0}\left(\mu_{x}-\mu_{z}\right)\right] \sin ^{2} \theta_{0}}
$$

- for TM waves:

$$
\sin ^{2} \theta=\frac{\varepsilon_{y 0} \mu_{x 0} \mu_{z 0} \mu_{z} \sin ^{2} \theta_{0}}{\varepsilon_{y} \mu_{x} \mu_{z} \mu_{z 0}-\left[\varepsilon_{y} \mu_{x} \mu_{z}\left(\mu_{x 0}-\mu_{z 0}\right)+\varepsilon_{y 0} \mu_{x 0} \mu_{z 0}\left(\mu_{x}-\mu_{z}\right)\right] \sin ^{2} \theta_{0}} .
$$

5. Directions of group velocity vectors in incident TE and TM waves

$$
\operatorname{tg} \beta_{T E}=\frac{\mu_{x 0}}{\mu_{z 0}} \operatorname{tg} \theta_{0} ; \operatorname{tg} \beta_{T M}=\frac{\varepsilon_{x 0}}{\varepsilon_{z 0}} \operatorname{tg} \theta_{0}
$$

are different even for the same angle of incidence. The directions of the group velocity vectors in the reflected waves are determined by formulas (79), taking into account the change in the direction of propagation. lar form:

6 . The directions of the group velocity vectors in the refracted TE and TM polarized waves have a simi-

$$
\operatorname{tg} \beta_{T E}=\frac{\mu_{x}}{\mu_{z}} \operatorname{tg} \theta ; \operatorname{tg} \beta_{T M}=\frac{\varepsilon_{x 0}}{\varepsilon_{z 0}} \operatorname{tg} \theta_{0},
$$

however, it must be borne in mind that the angle $\theta$ in (80) is determined by formulas (77) and (78).

7. For the reflection and refraction coefficients of TE and TM waves at the boundary of anisotropic media of rhombic symmetry, the Fresnel formulas [1-3] are valid. Moreover, the components $k_{z}$ and $k_{z 0}$ are determined on the basis of the indicatrix equations (71), (72).

$$
k_{z T E}^{2}=\frac{\omega^{2} \varepsilon_{y} \mu_{x} \mu_{z}}{\mu_{z}+\mu_{x} \operatorname{tg}^{2} \theta} ; k_{z T M}^{2}=\frac{\omega^{2} \mu_{y} \varepsilon_{x} \varepsilon_{z}}{\varepsilon_{z}+\varepsilon_{x} \operatorname{tg}^{2} \theta} .
$$

In refracted waves, the angle $\theta$ is determined by relations (77), (78).

Based on comparisons of the characteristics of TE and TM polarization waves (71)-(81), it can be concluded that the components of the magnetic permeability tensor have a determining, predominant effect on the characteristics of TE waves.

For the characteristics of TM waves, the anisotropy of the dielectric constant tensor is decisive.

A study of the anisotropic properties of locally isotropic inhomogeneous elastic media showed that averaging of one-dimensionally inhomogeneous media (the wavelength is much larger than the characteristic dimensions of the inhomogeneity) leads to the manifestation of the anisotropic properties of hexagonal symmetry by the medium.

Two and three-dimensionally inhomogeneous locally isotropic media, when averaged, have properties and are described by the parameters of rhombic anisotropy media [18].

Similar results were obtained and are valid for inhomogeneous, locally isotropic dielectric media.

\section{Results and discussion}

An analytical solution to the problems of reflection and refraction of plane electromagnetic waves TE and TM polarization at the boundary of anisotropic media of rhombic symmetry is constructed, the dependences on the direction of the wave vector $k_{0}$ (angle $\theta_{0}$ ) of the incident wave are determined:

- refraction angles of TE and TM polarization waves;

- amplitudes of reflected and refracted waves (reflection and refraction coefficients);

- directions of vectors of phase and group velocities in refracted waves;

- component of the vectors of the flow of electromagnetic energy of incident reflected and refracted waves;

- values of phase and group velocities in refracted TE and TM polarized waves.

The results obtained are applicable to the analysis of the processes of reflection and refraction of electromagnetic waves at the boundary of anisotropic media with higher symmetry. 


\title{
References
}

1 Ландау Л.Д. Электродинамика сплошных сред: учеб. / Л.Д. Ландау, Е.М. Лифшиц. — М.: Наука, 1982. —620 с.

2 Рязанов М.И. Электродинамика конденсированного вещества: учеб. пос. / М.И. Рязанов. — М.: Наука, 1984. — 304 с.

3 Калитиевский Н.И. Волновая оптика: учеб. пос. / Н.И. Калитиевский. — М.: Наука, 1971. — 376 с.

4 Виноградова М.Б. Теория волн: учеб. пос. / М.Б. Виноградова, О.В. Руденко, А.П. Сухоруков. — М.: Наука, 1990. — $432 \mathrm{c}$.

5 Рабинович М.И. Введение в теорию колебаний и волн: учеб. пос. / М.И. Рабинович, Д.И. Трубецков. — М.: Наука, 1984. - $432 \mathrm{c}$.

6 Дьелесан Э. Упругие волны в твердых телах. Применение и обработка сигналов: учеб. пос. / Э. Дьелесан, Д. Руайе. - М.: Наука, 1982. - 424 с.

7 Балакирев М.К. Волны в пьезокристаллах: учеб. пос. / М.К. Балакирев, И.А. Гилинский. - Новосибирск: Наука, 1982. - $239 \mathrm{c}$.

8 Filippov D.A. Magnetoelectric effect in bilayer magnetostrictive-piezoelectric structure / D.A. Filippov, T.A. Galichyan, V.M. Laletin // Theory and experiment, Applied Physics A. - 2014. — No. 115(3). — P. 1087-1091.

9 Zhang T. A new magnetoelectric composite with enhanced magnetoelectric coefficient and lower resonance frequency / T. Zhang, X. Yang, J. Ouyang, S. Chen, B. Tong, Y. Zhu, et al. // Applied Composite Materials. — 2013. — No. 21(4). — P. 579590 .

10 Osaretin I.A. Theoretical model for the magnetoelectric effect in magnetostrictive piezoelectric composites / I.A. Osaretin, R.G. Rojas // Physical Review B. - 2010. - No. 82(17). - Retrieved from https://journals.aps.org/prb/abstract/ 10.1103/PhysRevB.82.174415

11 Bichurin M.I. Electromechanical resonance in magnetoelectric layered structures / M.I. Bichurin, V.M. Petrov, S.V. Averkin, A.V. Filippov // Phys. Solid State. — 2010. — No. 52. - P. 2116-2122. $72 \mathrm{c.}$

12 Тлеукенов С.К. Электромагнитные волны в анизотропных средах / С.К. Тлеукенов. - Алматы: Эпиграф, 2017. -

13 Tleukenov S.K. Surface of wave vectors of electromagnetic waves in anisotropic dielectric media with rhombic symmetry / S.K. Tleukenov, A.M. Assilbekova // Telecommunication and Radio Engineering. - 2017. — No. 76(14). — P. 1231-1238.

14 Tleukenov S.K. Phase and group velocities of electromagnetic waves in a monoclinic crystal / S.K. Tleukenov, Z.K. Zhalgasbekova, Yu.K. Sirenko // Telecommunication and Radio Engineering. — 2019. — No. 78. — P. 1-10.

15 Тлеукенов С.К. Изучение электромагнитных полей в анизотропных средах / С.К. Тлеукенов, А.Т. Оспанов. — Алматы: Кенже пресс, 2001. — 67 с.

16 Tleukenov S.K. A method for the analytical description of coupled-field waves in various anisotropic media / S.K. Tleukenov // ActaMechanica. - 2014. — No. 225(12). - P. 3535-3547.

17 Tleukenov S.K. Structure of the matriciant for systems of ordinary differential equations of first order and its applications / S.K. Tleukenov, A. Bobeev, D. Sabitova // International Journal of Applied Mathematics and Statistics. - 2017. — No. 57(1). P. 209-217.

18 Tleukenov S.K. Anisotropic behavior and elastic moduli of average isotropic and anisotropic elastic media / S.K. Tleukenov // Thermal science and Engineering. - 2019. — No. 1(3). - P. 1-5.

\section{С.К. Тлеукенов, К.Н. Балабеков, З.К. Жалгасбекова}

\section{Ромбылық кристалдардың шекарасында ТЭ және ТМ поляризациялы толқындардың шағылу және сыну заңдылықтары}

\begin{abstract}
Мақалада ромбылық симметрияның анизотропты жартылай кеңістігінің шекарасындағы әртүрлі поляризациялы электромагниттік жазық толқындардын шағылу және сыну есебінің аналитикалық шешілуі берілген. Матрица әдісі негізінде поляризациялануы әртүрлі электромагниттік толқындардың сыну бұрыштары, шағылған және сынған толқындардың амплитудалары, топтық жылдамдықтар бағыты және электромагниттік энергия ағынының векторларын анықтаушы бұрыштары, түсетін толқынның толқындық векторына тәуелді болатын электромагниттік энергия ағындарының шамалары және олардың құраушылары анықталған. Поляризациясы әртүрлі электромагниттік толқындардың сыну көрсеткіші және толық ішкі шағылу бұрыштарын анықтау қарастырылған. Магниттік және диэлектрлік өтімділіктері тензорлар анизотропиясына поляризациялануы әртүрлі болып келетін электромагниттік толқындардың кинематикалық және энергетикалық сипаттамаларының тәуелділігі әртүрлі болатындығы көрсетілген. Поляризациясы толқынның таралу жазықтығына перпендикуляр (ТЭ толқындар) болып келетін электр кернеулігі векторының құраушысымен анықталатын электромагниттік толқындар үшін, шағылған және сынған толқындар сипаттамалары, жылдамдықтар индикатрисалары, таралу бұрыштары және т.б. басым жағдайда магниттік өтімділік тензоры құраушыларымен анықталған. Ал поляризациясы толқынның таралу бағытына перпендикуляр болып келетін магнит өрісі (ТМ толқындар) кернеулігінің құраушысымен анықталатын электромагниттік толқын жағдайында, барлық сипаттамалар көбіне диэлектрлік өтімділік тензоры құраушысына
\end{abstract}


тәуелді. Ромбылық симметриялы анизотропты ортаның шекарасында шағылған және сынған толқындардың коэффициенттерін анықтауға Френель формуласының дұрыстығы көрсетілген. Бірақта, бұл жағдайда Френель формуласына енетін толқын векторларының құраушылары олардың индикатрисасымен анықталған. Сонымен қатар, осы құраушылардың екінші ортадағы сыну бұрышына тәуелділігі ескерілуі керек.

Кілт сөздер: анизотропия, ромбылық симметрия, электромагниттік толқындар, шағылу, сыну, толқындардың сыну бұрыштары, фазалық және топтық жылдамдықтар, тығыздық векторы.

\title{
С.К. Тлеукенов, К.Н. Балабеков, З.К. Жалгасбекова
}

\section{Закономерности отражения и преломления волн ТЕ и ТМ поляризации на границе ромбических кристаллов}

\begin{abstract}
В статье аналитически решена проблема отражения и преломления электромагнитных плоских волн различной поляризации на границе анизотропных полупространств ромбической симметрии. На основе матричного метода найдены углы преломления электромагнитных волн различной поляризации, амплитуды отраженных и преломленных волн; углы, определяющие направление групповых скоростей и векторы потоков электромагнитной энергии; потоки электромагнитной энергии и их составляющие на направление волнового вектора падающей волны. Рассмотрено определение углов полного внутреннего отражения и показателя преломления электромагнитных волн различной поляризации. Показана принципиально разная зависимость кинематических и энергетических характеристик электромагнитных волн различной поляризации от анизотропии тензоров магнитной и диэлектрической проницаемости. Для электромагнитных волн, поляризация которых определяется компонентой вектора электрической напряженности, перпендикулярной плоскости распространения волны (ТЕ-волна), характеристиками отраженных и преломленных волн, показательными для скоростей, углов распространения и т.д., определяется в первую очередь компонентами тензора магнитной проницаемости. В случае электромагнитных волн, когда поляризация определяется компонентом напряженности магнитного поля (волна ТМ), перпендикулярной плоскости распространения волны, все характеристики зависят главным образом от компонент тензора диэлектрической проницаемости. Показана обоснованность формул Френеля для обозначения коэффициентов отраженной и преломленной волн на границе анизотропных сред орторомбической симметрии. Однако в этом случае компоненты волновых векторов, входящих в формулы Френеля, определяются их индикатрисами. Кроме того, необходимо учитывать зависимость этих составляющих от угла преломления во второй среде.
\end{abstract}

Ключевые слова: анизотропия, ромбическая симметрия, электромагнитные волны, отражение, преломление, углы преломления волн, фазовые и групповые скорости, вектор плотности.

\section{References}

1 Landau, L.D., \& Lifshits, E.M. (1982). Elektrodinamika sploshnykh sred [Continuum electrodynamics]. Moscow: Nauka [in Russian].

2 Ryazanov, M.I. (1984). Elektrodinamika kondensirovannoho veshchestva [Electrodynamics of condensed matter]. Moscow: Nauka [in Russian].

3 Kalitievskii, N.I. (1971). Volnovaia optika [Wave optics]. Moscow: Nauka [in Russian].

4 Vinogradova, M.B., Rudenko, O.V. \& Sukhorukov, A.P. (1990). Teoriia voln [Theory of waves]. Moscow: Nauka [in Russian].

5 Rabinovich, M.I., \& Trubetskov, D.I. (1984). Vvedenie v teoriiu kolebanii $i$ voln [Introduction to the theory of oscillations and waves]. Moscow: Nauka [in Russian].

6 Dieulesaint, E., \& Royer, D. (1982). Upruhie volny v tverdykh telakh. Primenenie i obrabotka sihnalov [Elastic waves in solids. Application and signal processing]. Moscow: Nauka [in Russian].

7 Balakirev, M.K., \& Gilinsky, I.A. (1982). Volny v pezokristallakh [Waves in piezocrystals]. Novosibirsk: Nauka [in Russian].

8 Filippov, D.A., Galichyan, T.A., \& Laletin, V.M. (2014). Magnetoelectric effect in bilayer magnetostrictive-piezoelectric structure. Theory and experiment, Applied Physics A, 115(3), 1087-1091.

9 Zhang, T., Yang, X., Ouyang, J., Chen, S., Tong, B., \& Zhu, Y., et al. (2013). A new magnetoelectric composite with enhanced magnetoelectric coefficient and lower resonance frequency. Applied Composite Materials, 21 (4), 579-590.

10 Osaretin, I.A., \& Rojas, R.G. (2010). Theoretical model for the magnetoelectric effect in magnetostrictive/piezoelectric composites. Physical Review B, 82(17). Retrieved from: https://journals.aps.org/prb/abstract/10.1103/PhysRevB.82.174415

11 Bichurin, M.I., Petrov, V.M., Averkin, S.V., \& Filippov, A.V. (2010). Electromechanical resonance in magnetoelectric layered structures. Phys. Solid State, 52, 2116-2122.

12 Tleukenov, S.K. (2017). Elektromahnitnye volny $v$ anizotropnykh sredakh [Electromagnetic waves in anisotropic media]. Almaty: Epihraph [in Russian]. 
13 Tleukenov, S.K., \& Assilbekova, A.M. (2017). Surface of wave vectors of electromagnetic waves in anisotropic dielectric media with rhombic symmetry, Telecommunication and Radio Engineering, 76(14), 1231-1238.

14 Tleukenov, S.K., Zhalgasbekova, Z.K. \& Sirenko, Yu.K. (2019). Phase and group velocities of electromagnetic waves in a monoclinic crystal, Telecommunication and Radio Engineering, 78, 1-10.

15 Tleukenov, S.K., \& Ospanov, A.T. (2001). Izuchenie elektromahnitnykh polei v anizotropnykh sredakh [Study of electromagnetic fields in anisotropic media]. Almaty: Kenzhe press [in Russian].

16 Tleukenov, S.K. (2014). A method for the analytical description of coupled-field waves in various anisotropic media, ActaMechanica, 225(12), 3535-3547.

17 Tleukenov, S.K., Bobeev, A., \& Sabitova, D. (2017). Structure of the matriciant for systems of ordinary differential equations of first order and its applications, International Journal of Applied Mathematics and Statistics, 57(1), 209-217.

18 Tleukenov, S.K. (2019). Anisotropic behavior and elastic moduli of average isotropic and anisotropic elastic media. Thermal science and Engineering, 1(3), 1-5. 